\title{
Gerçek Zamanlı Basınç Yönetimiyle Su Dağıtım Şebekesinde Su Kaybının Azaltılması
}

\author{
Mehmet Melih KOŞUCU ${ }^{1}$ \\ Ömer SARI ${ }^{2}$ \\ Mehmet Cüneyd DEMIREL ${ }^{3}$ \\ Samet KIRAN ${ }^{4}$ \\ Abdurrahman YILMAZ \\ Abdulbaki AYBAKAN6 \\ Enes ALBAY ${ }^{7}$ \\ V. Ş. Özgür KIRCA ${ }^{8}$
}

ÖZ

Su dağıtım sistemlerindeki su kayıplarının azaltılması su, enerji, arıtma ve zaman tasarrufu açısından oldukça gereklidir. Su kayıplarının azaltılması, ancak hidrolik model yardımıyla basınç yönetimi yapılarak efektif olarak gerçekleştirilebilir. Sabit basınç çıkışlı basınç düşürücü vanalarla bu işlem yapılmaya çalışıldığında ya kritik noktanın minimum basınç değerinin altına düşmesi, ya da basınç yönetiminden istenen verimin alınamaması muhtemeldir. Bu sebeple özellikle su tüketim paterninin büyük salınımlar gösterdiği büyük şehirlerde gerçek zamanlı kontrol yöntemiyle basınç yönetimi, kayıp su miktarını azaltmak açısından oldukça faydalıdır. Bu çalışmada iki önemli faaliyet yürütülmüştür. Bunlardan ilki,

Not: Bu yazı

- Yayın Kurulu'na 13 Aralık 2019 günü ulaşmıştır. 28 Eylül 2020 günü yayımlanmak üzere kabul edilmiştir.

- 31 Mart 2021 gününe kadar tartışmaya açıktır.

- https://doi.org/10.18400/tekderg.658870

1 İstanbul Teknik Üniversitesi, İnşaat Mühendisliği, Bölümü, İstanbul - kosucu@itu.edu.tr https://orcid.org/0000-0001-5907-6964

2 İstanbul Teknik Üniversitesi, İnşaat Mühendisliği, Bölümü, İstanbul - sari18@itu.edu.tr https://orcid.org/0000-0002-7556-6020

3 İstanbul Teknik Üniversitesi, İnşaat Mühendisliği, Bölümü, İstanbul - mehmet.demirel@itu.edu.tr https://orcid.org/0000-0003-4402-906X

4 İstanbul Teknik Üniversitesi, İnşaat Mühendisliği, Bölümü, İstanbul İstanbul Su ve Kanalizasyon İdaresi, İstanbul - kiransa@itu.edu.tr https://orcid.org/0000-0001-7826-6157

5 İstanbul Teknik Üniversitesi, Kontrol ve Otomasyon Mühendisliği, İstanbul - yilmazabdurrah@itu.edu.tr https://orcid.org/0000-0001-8946-6664

6 İstanbul Teknik Üniversitesi, Kontrol ve Otomasyon Mühendisliği, İstanbul - aybakana@itu.edu.tr https://orcid.org/0000-0002-8912-547X

7 İstanbul Teknik Üniversitesi, Bilgisayar Mühendisliği Bölümü, İstanbul - albay@itu.edu.tr https://orcid.org/0000-0001-8228-8711

8 İstanbul Teknik Üniversitesi, İnşaat Mühendisliği, Bölümü, İstanbul - kircave@itu.edu.tr https://orcid.org/0000-0003-1374-5039 
hipotetik bir şebekenin hidrolik modelinde Gerçek Zamanlı basınç yönetiminin farklı su kaybı senaryoları altında gerçekleştirilerek bir hassasiyet analizi yapılmasıdır. İkincisi ise gerçek bir şebekenin hidrolik modelinde Gerçek Zamanlı basınç yönetimi uygulanarak bu yöntemin su kayıplarını azaltmada başarılı olduğunun ortaya konmasıdır.

Anahtar Kelimeler: Su dağıtım sistemleri, hidrolik modelleme, gerçek zamanlı kontrol.

\section{ABSTRACT \\ Water Leakage Reduction in the Water Distribution Network with Real Time Pressure Management}

Reducing water leakages in water distribution systems is essential in terms of water, energy, treatment and time savings. However, the reduction of water leakages can only be realized effectively by pressure management with the help of a hydraulic model. When attempting to do this task with pressure reducing valves with constant pressure output, it is possible that either the critical point will fall below the minimum pressure value or that the desired efficiency cannot be obtained from the pressure management. For this reason, pressure management by real-time control method is very beneficial especially in large cities where the water consumption pattern shows large oscillations. Two important activities were carried out in this study. The first one is to perform a sensitivity analysis by performing Real Time pressure management under different water loss scenarios in a hypothetical network. The second is to demonstrate that this method is successful in reducing water losses by applying Real Time pressure management in the hydraulic model of a real network.

Keywords: Water distribution systems, hydraulic modelling, real time control.

\section{GíRiş}

Su dağıtım sistemlerinde yüksek basınçların etkisiyle ortaya çıkan su kayıpları, su kaynaklarından yeterince istifade edilememesine sebep olduğu gibi, sisteme (pompalar vasıtasıyla) enerji verilmesi ve arıtma tesislerinde suyun arıtılması süreçlerinden dolayı ciddi zayiatlara da yol açmaktadır. Öyle ki, pompa ile terfi ettirilmiş ve arıtma tesisinde arıtılmış su, borulardan sızarak sistem dışına çıktığı için enerji ve arıtma kapasitesi boş yere kullanılmış olmaktadır. Bu kayıpların yanında yerleşim birimlerindeki nüfus artışı dolayısıyla temin edilen su ihtiyacı zamanla artmakta, tabii olarak su idareleri bu durumda yeni su kaynaklarından su temin etmeye yönelmektedir. Hâlbuki yeni kaynaklar aramak yerine öncelikle mevcut su kayıplarının azaltılmaya çalışılması hem ekonomik, hem de teknik açıdan oldukça gereklidir. Su kayıplarının azaltılması temel olarak iki faaliyetin gerçekleştirilmesiyle mümkün olabilir: 1) Su dağıtım sisteminde hidrolik modelleme yardımıyla gerçekleştirilebilen basınç yönetimiyle [1]. 2) Yüksek basınçlar sebebiyle oluşan boru hasarlarının giderilmesiyle [2]. Boru hasarları, bölgedeki trafik yüküne, boru malzemesinin cinsine ve yataklama kalitesine de bağlı olduğundan düşük basınçlarda da meydana gelebilir. Fakat yüksek basınçlı boruda hasarın büyüklüğü ve yayılma mesafesi aynı şartlardaki düşük basınçlı boruya göre daha fazladır.

Her ne kadar sadece boruların tamir edilmesi geçerli bir çözüm gibi gözükse de, hidrolik modellemeyle basınç yönetimi yapılmadığında yüksek basınçlar tekrar ortaya çıkmakta ve 
borular tekrar tahrip olmaktadır. Dolayısıyla hidrolik modellemeyle basınç yönetimi olmadan boruların onarımı yoluna gitmek palyatif bir çözüm olarak karşımıza çıkmaktadır. Bu çalışma kapsamında, su dağıtım sistemindeki kayıpların bir hidrolik model yardımıyla basınç yönetimi yapılarak azaltılması planlanmaktadır. Böylece suyun boşa akmasının önüne geçileceği gibi, ülkenin ciddi bir maliyet yükünden kurtarılması hedeflenmektedir.

Su dağıtım sisteminde yüksek olan basınçları düşürmek için basınç düşürücü vanalar (BDV) kullanılmaktadır [3]. Bu tip vanalar, menba basıncının yüksek olduğu durumlarda aktif olarak çalışır ve debiyi değiştirmeden basınç değerini düşürerek boruların hasar görme riskini azaltır. Basınç düşürücü vanalar her ne kadar basıncı düşürse de, bu tip vanalarda çıkış basıncının sabit olarak verilmesi, yüksek su tüketimi saatlerinde basınçların şebekede izin verilen en düşük servis basıncının bile altına düşmesine sebep olabilmektedir. $\mathrm{Bu}$ ise kullanıcılara efektif bir şekilde suyun iletilmesinin önünde bir engel oluşturacağından su kayıplarının önüne geçmek isterken başka türlü bir zararın doğması durumu ortaya çıkacaktır. Bu sebeple, gerçek zamanlı olarak kontrol edilebilen bir vananın su dağıtım sisteminin kritik bir noktasından (yani en yüksek kotlu noktasından) sinyal alarak basıncı buna göre ayarlaması, yüksek basınçların ortaya çıkmasını önlemesinin yanında sistemin tasarım aşamasında öngörüldüğü gibi işlemesini ve günün her saatinde kullanıcılara suyun iletilebilmesini sağlayabilir. Yüksek basınçların sebep olduğu su kayıplarının Türkiye'nin birçok şehrinde \%50-60 mertebesinde [4] olduğu düşünüldüğünde gerçek zamanlı kontrol uygulamasının su dağıtım sisteminde tatbik edilmesinin önemi ortaya çıkmaktadır.

Araujo ve diğ. [5], hipotetik bir şebeke üzerinde enerji kırıcı vanaların sayısının ve konumunun optimizasyonunu yaparak bu vanaların kullanımının su kayıplarını azaltmada etkili olduğunu göstermiştir. Campisano ve diğ. [6], Araujo ve diğ. [5] tarafından kullanılan hipotetik su dağıtım şebekesini kullanmış, bu şebekede gerçek zamanlı kontrol edilen iki vananın iki farklı kritik noktadan sinyal alarak basınç yönetimini gerçekleştirmesini sağlamıştır. Campisano ve diğ. [7], gerçek zamanlı kontrol edilen vananın PID sistemiyle yönetilmesi sırasında meydana gelen instabiliteyi asgariye indirmek için yapılan bir kalibrasyonun yöntemini ortaya koymuştur. Creaco ve diğ. [8], gerçek zamanlı kontrol edilen vanayı kararsız akım koşullarında modellemiş ve modelin instabil olmaması için gerekli olan minimum zaman adımını belirlemiştir.

Campisano ve diğ. [9], 9 tane basınç düşürücü vananın bulunduğu [10] ve basınçlar ile su kaybı miktarının buna rağmen bir hayli yüksek olduğu [11] Norveç'in Oslo şehrinin Oppegard bölgesinin su dağıtım sisteminin hidrolik modelini kurmuş, ve su kayıplarının azaltılabileceğini göstermiştir. Fontana ve diğ. [13], gerçek zamanlı kontrol edilen basınç düşürücü vananın stabilite koşulunu açıklamış, laboratuarda deneylerini yapmış ve bu deneyi sayısal olarak modellemiştir. Fontana ve diğ. [14], tarafından yapılan saha deneyleri sonucunda gerçek zamanlı kontrolle yapılan basınç yönetiminin sabit çıkışlı geleneksel basınç yönetimine göre yüksek basınç ve su kayıplarıyla mücadelede daha etkili olduğu anlaşılmıştır.

Su dağıtım sistemindeki su kayıplarının başlıca sebebinin sistemdeki yüksek basınçlar olduğu bilinmektedir [15]. Fakat yüksek basınçlar sistemde kararsız halde bulunup günün her saatinde ortaya çıkmamaktadır. Suyun az kullanıldığı gece saatlerinde su dağıtım sistemindeki akım hızları düşük olduğu için yüksek basınçların ortaya çıktığı bilindiğine göre, su kayıplarının önüne geçmek için bu saatlerde ortaya çıkan yüksek basıcçları düşürmenin gerektiği anlaşılmaktadır. Fakat sistem girişindeki basıncın sabit bir değere 
düşürülmesi, tüketimin fazla olduğu saatlerde izin verilen minimum servis basıncı değerinin altına düşülmesine sebep olabilmektedir. Tam da bu noktada sistemdeki basınçların gerçek zamanlı olarak yönetilmesinin önemi devreye girmektedir. Gerçek zamanlı basınç yönetimi, sistemin zamana bağlı değişen özelliklerine göre şekil almasının yanında, hidrantların açılması gibi sistemdeki basınçların ani olarak değiştiği özel durumlarda da ciddi fayda sağlamaktadır [16]. Bu sebeple bu çalışma kapsamında gerçek zamanlı basınç yönetiminin basınç düşürücü vana ile yapılması planlanmaktadır.

Literatürde, kritik noktanın alacağı farklı basınç değerleri ile su dağıtım şebekesinin alacağı farklı kayıp katsayıları ve kayıp kuvvet derecelerinin (Kayıp katsayısı ve kayıp kuvvet derecesi parametreleri hakkında detaylar bölüm 3.2.1.'de verilmiştir) su kayıplarını nasıl etkilediğinin ortaya konduğu, yani bir nevi hassasiyet analizinin yapıldığı bir çalışma bulunmamaktadır. Bu çalışmanın başlıca amacı, literatürdeki bu eksikliğin, hipotetik bir model üzerinde yürütülerek bir parametrik çalışma ile giderilmesidir. Çalışmanın bir diğer hedefi ise gerçek zamanlı basınç yönetiminin gerçek bir su dağıtım şebekesinin hidrolik modeli üzerinde efektif olarak uygulanabileceğinin gösterilmesidir. Çalışmada gerçek bir uygulama örneği olarak, mevcut basınç yönetim sistemindeki problemleri dolayısıyla Sultanbeyli ilçesi su dağıtım şebekesi seçilmiştir. Böylece gerçek zamanlı basınç yönetiminin işletmedeki faydalarının ortaya konması ve genel kullanımda yaygınlık kazanarak bu yöntemle elde edilecek faydaların arttırılması hedeflenmiştir.

\section{GERÇEK ZAMANLI KONTROL VE PID}

Gerçek zamanlı kontrol (GZK), adından da anlaşılacağı üzere bir sistemin veya sistemdeki bir parametrenin zamanla birlikte meydana gelen bozucu etkilere rağmen dinamik bir şekilde kontrol edilmesidir. Bu sisteme literatürde "Kapalı Çevrim Kontrol" veya "Geri Beslemeli Kontrol" de denmektedir. Bu kontrol sisteminde, modelin veya deney düzeneğinin verdiği çıktı ile referans değeri karşılaştırılır ve aralarındaki hata sinyali esas alınarak kontrol algoritması ortaya konur. Şekil 1'de kapalı çevrim kontrol sisteminin ana yapısı gösterilmiştir. Sistemin çıktısı her zaman adımında kaydedilip referans değerine getirilmeye çalışılmaktadır. Bu işlem ise geri besleme birimi ve kontrolör yardımıyla bozucu etkenlere rağmen yapılmaktadır.

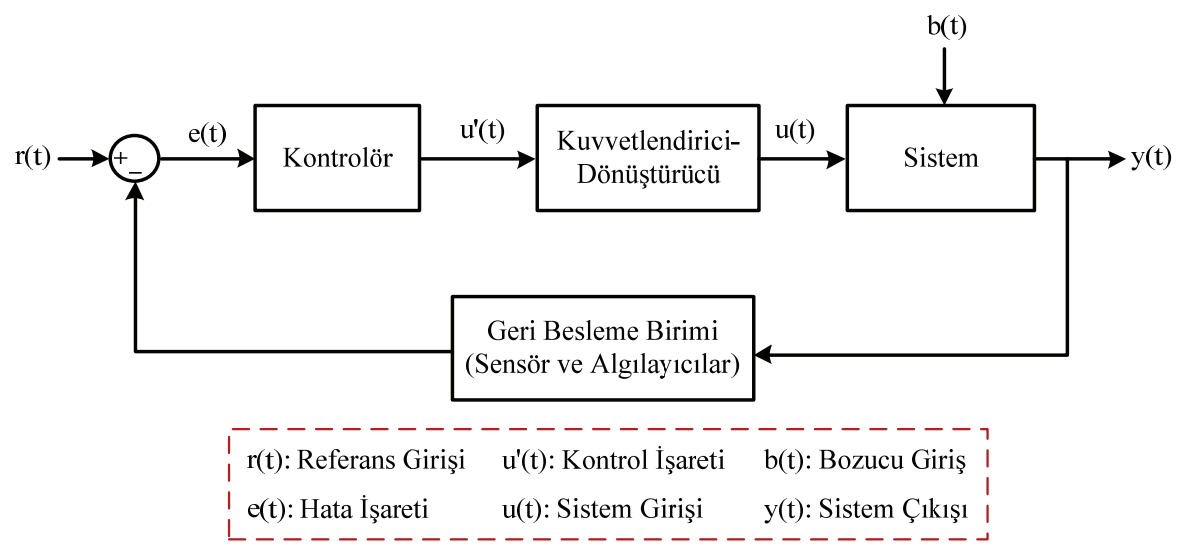

Şekil 1 - Kapalı Çevrim Kontrol Sistemi [17] 
Endüstriyel kontrol sistemlerinde kontrolörlerin aç-kapa yerine hatanın değerine bağlı olarak zamanda sürekliliği olan bir çıkış üretmesi istenir. Su dağıtım şebekesinde de basıncın efektif bir şekilde yönetimi, vananın tamamen açılması veya kapanmasıyla değil, açıklık değerinin sistemin verdiği hataya göre değişmesiyle sağlanır. Bu gerçek zamanlı müdahale en yaygın kullanılan kapalı çevrim kontrol sistemlerinden olan PID ile yapılabilmektedir. PID ifadesi, Proportional (Oransal), Integral (Toplam-İntegral) ve Derivative (Türev) kelimelerinin baş harfleriyle oluşturulmuştur. Proportional terimi, hata miktarı oranında değişimi, Integral terimi, geçmiş hataların toplamını, Derivative terimi ise hatanın zamanla değişim miktarını esas alarak sistemin kontrol edilmesini sağlar. PID Kontrol Sistemi'ne ait blok diyagramı Şekil 2'de verilmiştir.

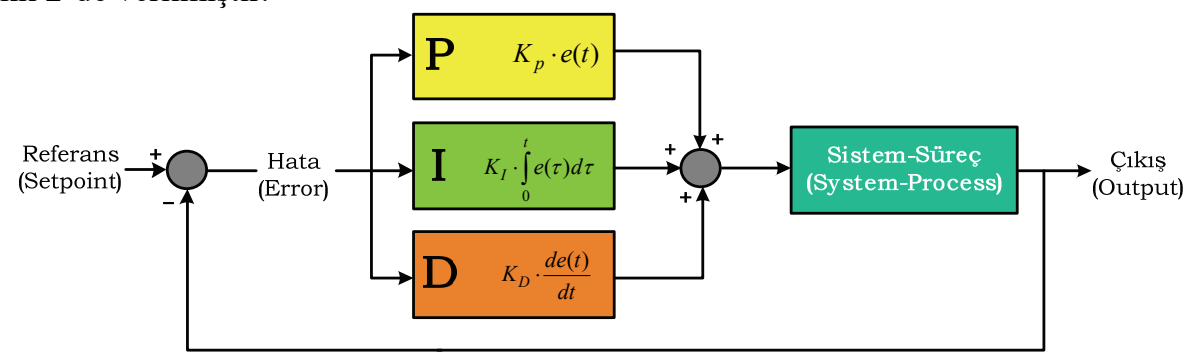

Şekil 2 - PID Kontrolör Blok Diyagramı [18]

Şekil 2'de e(t) zamanın fonksiyonu olarak hatayı; $K_{P}, K_{I}$ ve $K_{D}$ ise sırasıyla sistemin oransallık, integral ve türev sabitlerini göstermektedir. Bu çalışma kapsamında PID kontrolör kullanılarak su dağıtım şebekesinin kritik noktasındaki basıncın sabit kalması hedeflenmiştir. İleriki bölümlerde buna daha detaylı değinilecektir.

\section{HIPOTETIK MODEL}

Hipotetik Model, EPANET 2 adlı yazılım kullanılarak oluşturulmuştur. EPANET 2, Amerikan Çevre Koruma Ajansı tarafından su dağıtım sistemlerinin modellenmesi amacıyla kullanıma sunulmuş açık kaynak kodlu bir yazılımdır. Su dağıtım şebekesinde hesap yaparken EPANET 2'nin kullandığı algoritma, Todini ve Pilati [19] tarafından literatüre aktarılan Küresel Gradyen Algoritması’dır (Global Gradient Algorithm) [20].

\subsection{Hipotetik Model'in Girdileri}

GZK uygulamasına geçmeden önce kurulan örnek şebeke tanıtılacaktır. Şekil 3a'da hipotetik şebeke, düğüm noktasının kotlarıyla birlikte verilmiştir. Boruların üzerindeki siyah rakamlar boru numarasını, düğüm noktalarının üzerindeki siyah rakamlar düğüm noktası numarasını, yine dügüum noktasının üzerindeki kırmızı rakamlar da noktanın kotunu metre cinsinden göstermektedir. Hipotetik şebekede 1 numaralı düğüm noktası olan rezervuardan 25 adet düğüm noktasına su iletilmektedir. Rezervuardan gelen akım cazibeli olarak basınç düşürücü vanayı geçerek şebekeye girmektedir. Öncelikle genel işletme koşulları olan basınç düşürücü vananın hiç çalışmadığ 1 durum ile sabit çıkış verdiği durumlar incelenecektir. Şebekedeki boruların uzunluk ve çap bilgileri Şekil 3b ve Şekil 3c'de verilmiştir. 


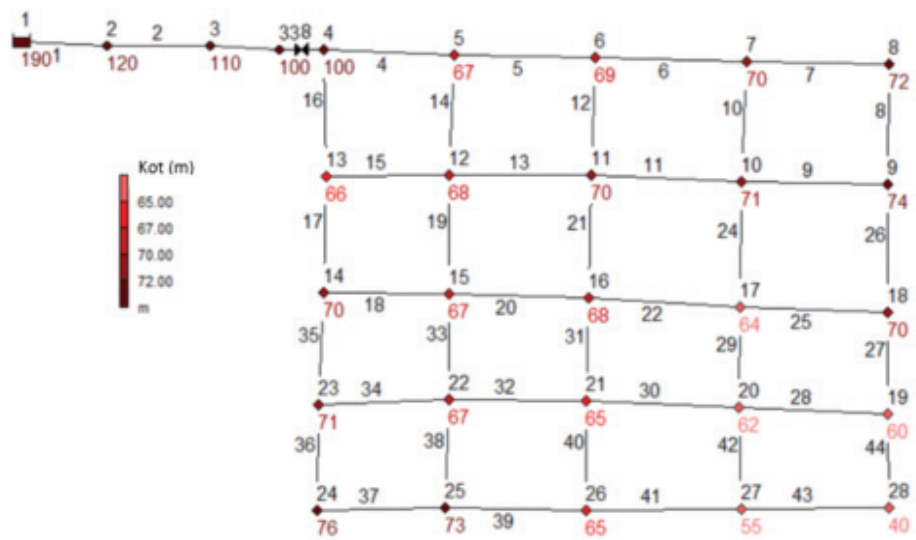

Şekil $3 a$ - Hipotetik Su Dă̆ıtım Sistemindeki düğ̈̈m noktalarının kotları

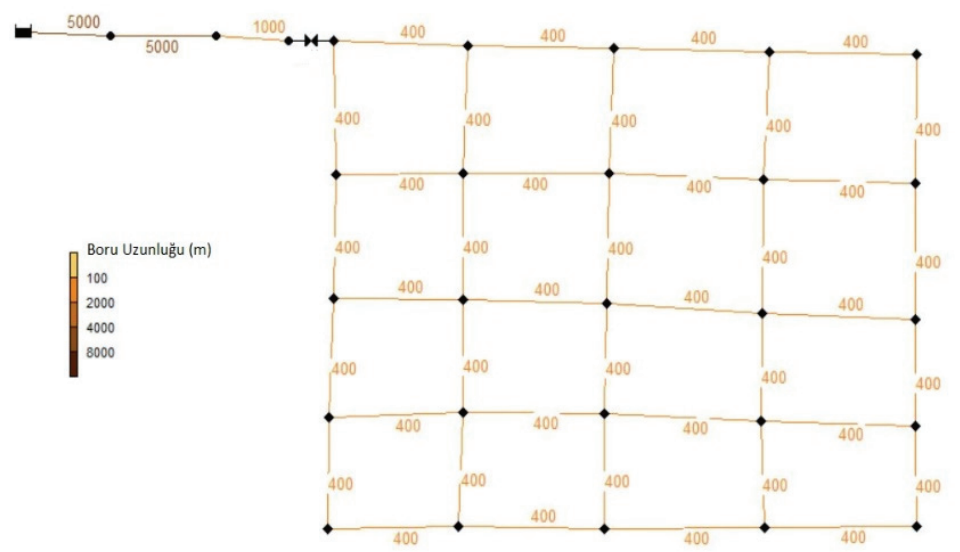

Şekil 3b - Hipotetik Su Dağıtım Sistemindeki boruların uzunlukları

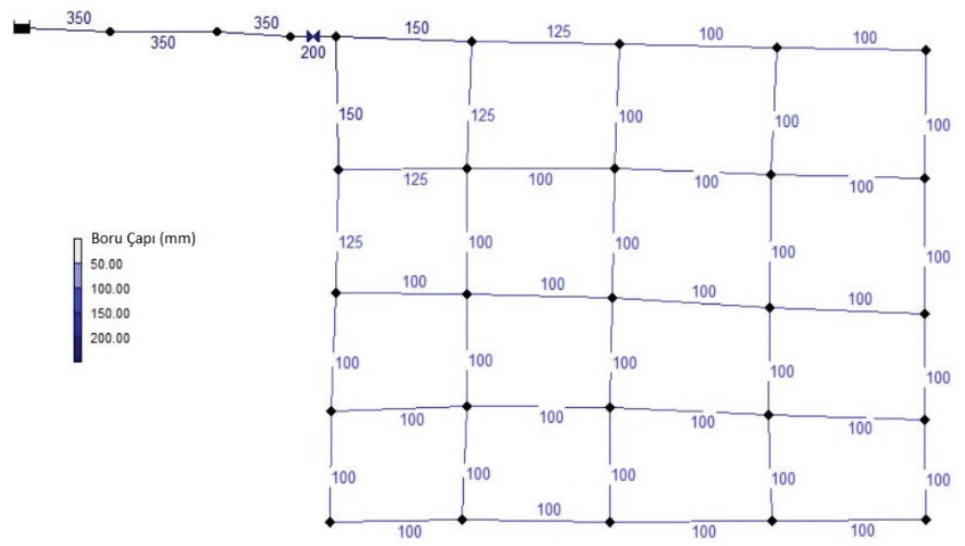

Şekil 3c - Hipotetik Su Dă̆ıtım Sistemindeki boruların çapları 
Sistemde 1, 2 ve 3 no'lu düğüm noktaları hariç bütün düğüm noktalarında abone tüketimi bulunmaktadır. Şekil 4'te şebekenin bir düğüm noktasındaki saatlik talep değerleri verilmiştir. Buradaki talep değerleri Kıran'ın [21] çalışmasında yer alan Sultanbeyli modelinden yararlanılarak alınmıştır.

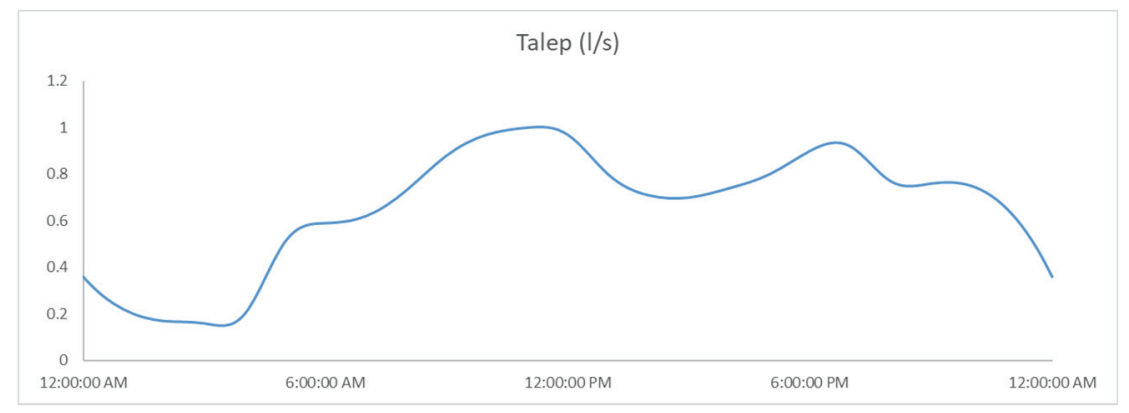

Şekil 4 - Sistemin dügüm noktalarındaki saatlik su talebi değerleri

\subsection{Hipotetik Model'deki Senaryolar ve Senaryoların Çıktıları}

Bu bölümde basınç yönetiminin hiç yapılmadığı ve basıncın konvansiyonel basınç düşürücü vana ile su dağıtım şebekesi girişinde sabit bir değer aldığı senaryolar (klasik işletme durumu) incelenecektir.

\subsubsection{Hipotetik Hidrolik Modelde Su Kaybı ve Basınç}

Kurulan hipotetik modelde kayıp su miktarının farklı seviyelerine göre 6 farklı senaryo denenmiştir. Kayıp su miktarını hesaplamada kullanılan ifade şu şekildedir [22]:

$q_{l}=C x P^{x}$

Denklem (1)'de ql kayıp su debisi, P, düğüm noktasındaki metre cinsinden basınç değeri $(p / \gamma)$, C kayıp katsayısı, $\mathrm{x}$ ise kayıp kuvvet derecesidir. C değeri $10^{0}$ ile $10^{-10}$ arasında değerler alırken [2], [5], [10], [23], x değeri ise 0.5 ile 1.5 arasında değerler almaktadır [24]. $\mathrm{Bu}$ çalışmada $\mathrm{C}$ ve x parametrelerinin farklı değerleri için oluşturulan 6 senaryo Çizelge 2'de verilmiştir.

Çizelge 2 - 6 Farklı Senaryoya ait Kayıp Katsayıları ve Kuvvet Dereceleri

\begin{tabular}{ccccccc}
\hline Senaryo & 1 & 2 & 3 & 4 & 5 & 6 \\
\hline $\mathrm{C}$ & 0.02 & 0.02 & 0.015 & 0.015 & 0.01 & 0.01 \\
$\mathrm{x}$ & 1.18 & 1.00 & 1.18 & 1.00 & 1.18 & 1.00 \\
\hline
\end{tabular}


Çizelge 2'de görüldüğü üzere kayıp katsayıları 0.02, 0.015 ve 0.01 değerlerini alırken, kayıp kuvvet dereceleri ise 1.18 ve 1.00 değerlerini almıştır. Kayıp katsayısı değeri, ilgili şebekedeki basınç yüksekliği değerleri, bölgedeki trafik yükü, bölgenin zemin cinsi ve boru malzemesinin kalitesi gibi değişkenlere bağlıdır. Esasen hidrolik modelde bu katsayı belirlenirken şebekedeki su kaybı oranı dikkate alınır ve prototiple model arasındaki uyumsuzluk giderilir. Mesela gerçek şebekedeki su kaybı oranı \%30 ise bu şebekenin hidrolik modelindeki su kaybı oranının da \%30 olması için uygun bir kayıp katsayısı seçilir ki model kalibre edilmiş olsun [10]. Kayıp kuvvet derecelerinin 1.00 ve 1.18 olarak alınmasının ise gerçekçi olduğu bilindiğinden bu değerler esas alınmıştır [5] [24]. Çizelge 2'deki farklı senaryolarda, basınç düşürücü vana tamamiyle inaktif iken kritik nokta olan 24. düğüm noktasındaki, ve en düşük kota sahip olan (bir diğer ifadeyle maksimum basınçlı olan) 28. Düğüm noktasındaki basınç değerlerinin gün içindeki değişimi, farklı $\mathrm{C}$ değerleri için Şekil 5a'da, 5b'de ve 5c'de verilmiştir. Bu şekillerde görüleceği üzere sistemdeki basınçlar 10-15 m'lik bir bant içinde salınım göstermektedir. Hamilton ve McKenzie [25], gündüz ve gece basınçları arasında ciddi salınımlar olan sistemlerde gerçek zamanlı kontrolün uygulanmasını tavsiye etmiştir. Buna göre bu sistemde de gerçek zamanlı kontrolün tatbik edilmesinin gerekli ve yerinde olduğu anlaşılmıştır.

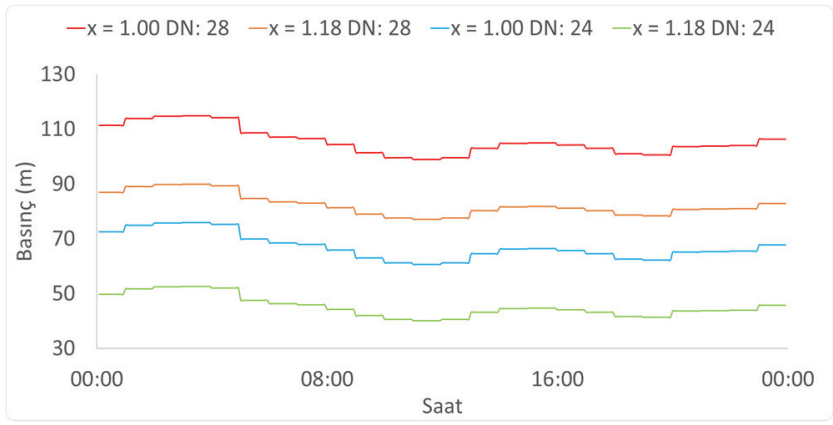

Şekil $5 a-C=0.02$ ve Basınç Düşürücü Vana inaktif iken 24 ve 28 numaralı düğüm noktalarının basınç değerleri.

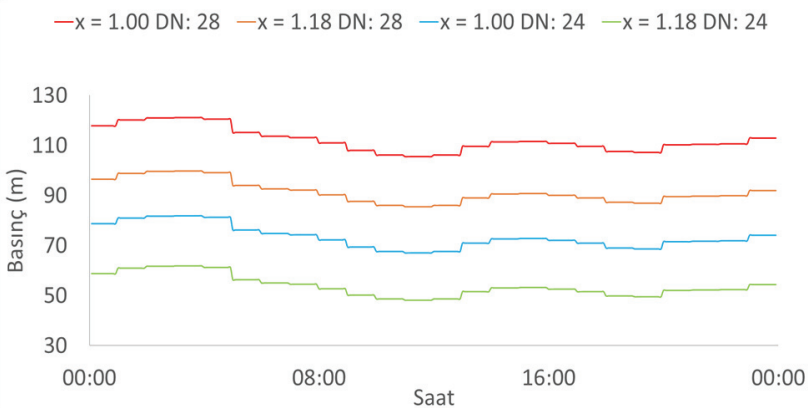

Şekil $5 b-C=0.015$ ve Basinç Düşürücü Vana inaktif iken 24 ve 28 numaralı düğüm noktalarının basinç değerleri. 


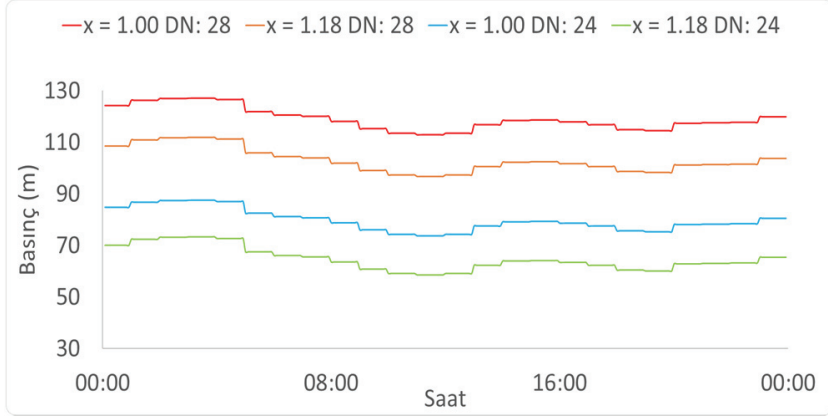

Şekil 5c-C =0.01 ve Basinç Düşürücü Vana inaktif iken 24 ve 28 numaralı düğüm noktalarının basınç değerleri.

\subsubsection{Hipotetik Hidrolik Modelde Konvansiyonel Basınç Yönetimi}

Bilindiği üzere su dağıtım şebekelerinde meydana gelen yüksek basınçları düşürmek için sabit çıkış basıncı veren basınç düşürücü vanalar sıklıkla kullanılmaktadır. Bu çalışma kapsamında kurulmuş olan hipotetik modelde de gerçek zamanlı basınç yönetimi yapılmadan önce sabit çıkış basıncı veren konvansiyonel vananın kritik noktada ve en düşük kotlu noktada vereceği basınç değerleri hidrolik model yardımıyla hesaplanmıştır. Basınç düşürücü vananın çıkış basınç değeri, kritik nokta basıncının 20 m'nin altına inmeyeceği duruma göre minimize edilmiştir. Buna göre 6 farklı senaryodaki basınç düşürücü vana çıkış basıncı değerleri Çizelge 3'te verilmiştir.

Çizelge 3 - Sabit Çıkışlı Basınç Düşürücü Vana'daki Çıkış Basıncı değerleri

\begin{tabular}{cccc}
\hline Senaryo & C & x & BDV Çıkış Basıncı $(\mathrm{m})$ \\
\hline 1 & 0.02 & 1.18 & 33 \\
2 & 0.02 & 1.00 & 26 \\
3 & 0.015 & 1.18 & 30 \\
4 & 0.015 & 1.00 & 25 \\
5 & 0.01 & 1.18 & 26 \\
6 & 0.01 & 1.00 & 23 \\
\hline
\end{tabular}

Çizelge 3'te verilmiş olan çıkış basınçlarının su dağıtım şebekesi girişinde bulunması elbette basınç yönetimi yapılmayan duruma göre sistemdeki basınçları ciddi miktarda değiştirecektir. Buna göre hidrolik model yardımıyla hesaplanmış olan kritik noktadaki ve en düşük kotlu noktadaki günlük basınç değişimi grafikleri Şekil 6'da, 7'de ve 8'de verilmiştir. 

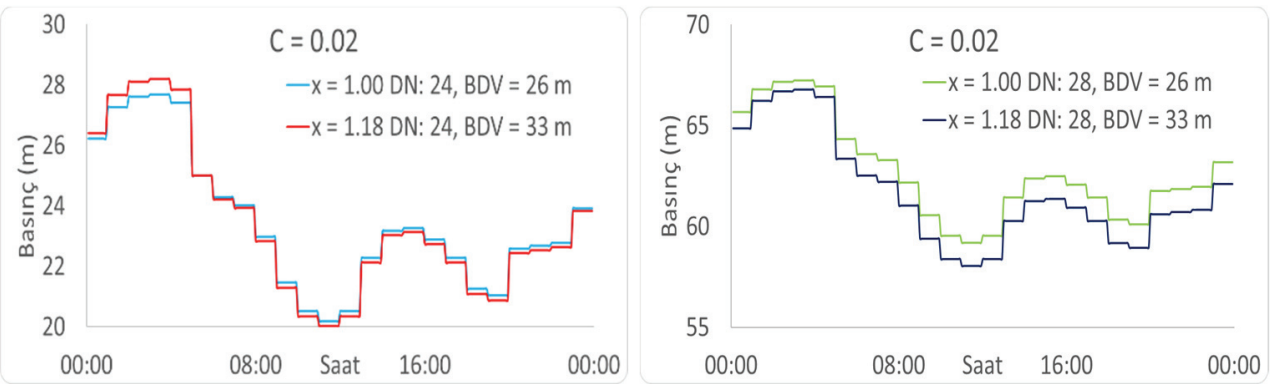

Şekil 6 - C = 0.02 ve Basınç Düşürücü Vana çalışırken a) 24 ve b) 28 numaralı düğ̈̈̈m noktalarının basınç değerleri.
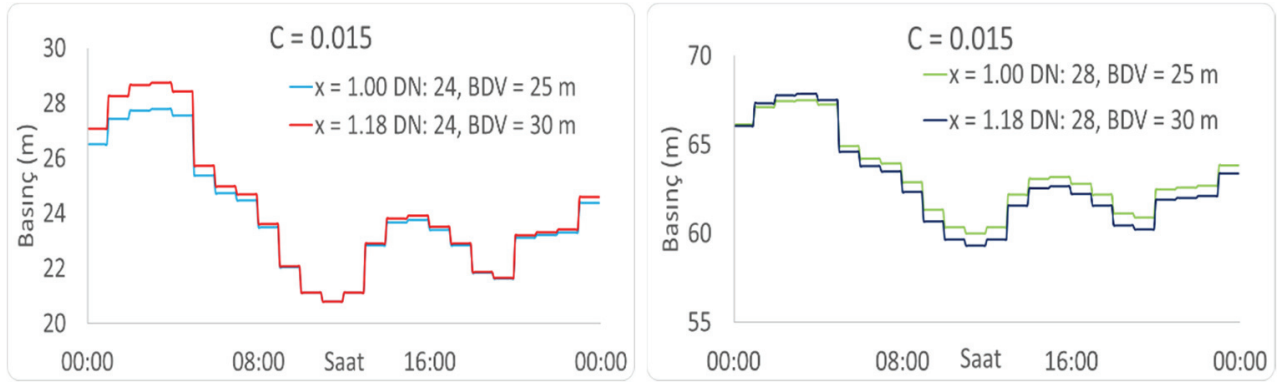

Şekil 7 - $C=0.015$ ve Basınç Düşürücü Vana çalışırken a) 24 ve b) 28 numaralı dügümm noktalarının basınç değerleri.
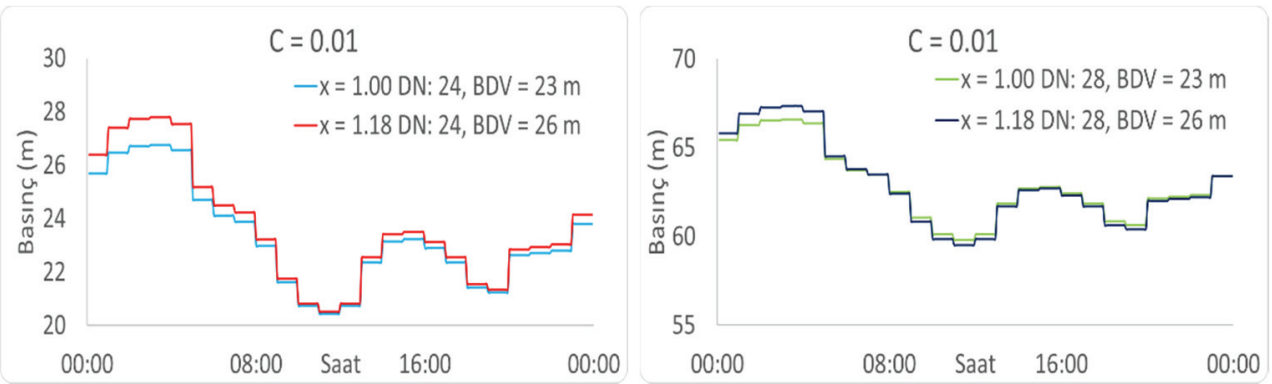

Şekil $8-C=0.01$ ve Basınç Düşürücü Vana çalışırken a) 24 ve b) 28 numaralı düğ̈̈m noktalarının basınç değerleri.

Şekil 6, 7 ve 8'den anlaşıldığı kadarıyla basınç düşürücü vananın inaktif olduğu duruma göre sistemin basınçları kayda değer miktarda düşmüştür. Fakat su dağıtım şebekesindeki izin verilen minimum servis basıncının $20 \mathrm{~m}$ olduğu kabul edilirse basınç değerinin daha da düşürülmesinin mümkün olduğu ve bunun sistemin işletimi ve su kayıplarının önlenmesi açısından faydalar ortaya çıkaracağını vurgulamak gerekir. Bu sebeple sistemdeki basınçları 
minimize etmek ve kayıpları azaltmak için gerçek zamanlı kontrolün uygulanacağı daha önce de belirtilmişti

\section{HİPOTETIKK HIDDOLİK MODELDE GERÇEK ZAMANLI KONTROL}

24 numaralı düğüm noktasının -yani kritik noktanın- sabit basınç düşürücü vana ile basınç yönetimi yapıldığında 28 m'ye varan basınç değerlerine sahip olabildiği Şekil 6, 7 ve 8'de görülmektedir. $\mathrm{Bu}$ değer her ne kadar düğüm noktalarından su alan abonelere suyun iletilebilmesi için gerekli olan minimum basınç değerinin üstündeyse de, minimum basınç sınırı şartını ihlal etmemek kaydıyla bu değerin altına inmek sistemin işletim süresinin ve kalitesinin artmasına ve sistemdeki kayıpların azaltılmasına önayak olacaktır. Bu sebeple sabit çıkışlı basınç düşürücü vana yerine gerçek zamanlı olarak sistemin kritik bir noktasından sinyal alıp ona göre basıncı düşüren bir basınç düşürücü vananın kullanımı daha avantajlıdır. Kritik noktadan sinyal alarak yapılan basınç yönetimi, kısaca GZK ile basınç yönetimi olarak da adlandırılmaktadır. Efektif bir gerçek zamanlı kontrol için su dağıtım şebekesinin hemen girişindeki basınç düşürücü vananın kritik noktayı kontrol etmesi gerekmektedir. Çünkü başka bir noktayı kontrol etmesi durumunda kritik noktanın basıncının izin verilen minimum servis basıncından aşağı inmesi söz konusu olabilmektedir. Kritik noktadaki basınç bu değerin altına düşerse de kullanıcılara su temin edilememesi riski ortaya çıkacaktır ki, bu da istenmeyen bir durumdur.

$\mathrm{Bu}$ çalışmada kullanılan ve açık kaynak kodlu bir yazılım olan EPANET 2, diğer programlama dilleriyle ve onların arayüzleriyle iletişime geçebilmektedir. Gerçek Zamanlı Kontrolün su dağıtım sisteminde uygulanması amacıyla Python (3.7.2) dilinde yazılmış bir PID kontrol algoritmasının hazırlanması ve bu algoritmanın EPANET 2'de kurulmuş olan hidrolik model ile eşgüdümlü biçimde çalışması kararlaştırılmıştır. Modelde kritik noktadan sinyal alan vananın, yerel yük kaybını her bir zaman adımında güncelleyerek kritik noktanın basıncını 25 m'de, 24 m'de, 23 m'de, 22 m'de, 21 m'de ve 20 m'de tutması durumlarını esas alan 6 farklı senaryo kurgulanmıştır. Zaman adımı $(\Delta \mathrm{T}), 5$ dakika seçilerek hassas bir kontrolün gerçekleştirilmesi amaçlanmıştır. Kontrol sistemindeki PID kontrolör çalışma prensibi ve giriş-çıkış bağıntılarındaki parametreler aşağıdaki gibi tanımlanmıştır.

$e[n]=P_{\text {ref }}-P_{24}[n]$

$\Delta e[n]=e[n]-e[n-1]$

$t=n \times \Delta T$

$h_{k}=k \times \frac{V^{2}}{2 g}$

$k=\frac{2 g \times h_{k}}{V^{2}}$

Burada Referans Basıncı $\left(P_{\text {ref }}\right)$ 25-20 m arasındaki tam sayılar olmak üzere 6 farklı senaryoya ait basınç değerlerini, $\mathrm{P}_{24}[\mathrm{n}] 24$ numaralı düğüm noktasının $\mathrm{n}$. zaman adımındaki basınç değerini, e[n] ve e[n-1] sırasıyla n. ve n'den bir önceki zaman adımındaki hataları ve $\Delta \mathrm{e}[\mathrm{n}]$ 
n. zaman adımındaki hatanın değişimini ifade etmektedir. Benzer şekilde hk basınç düşürücü vanadaki toplam yük kaybını, k yerel yük kaybı katsayısını, V ise vananın içinden geçen akımın kesitsel ortalama hızını göstermektedir. Ayrıca n. zaman adımındaki gerçek zaman değeri (t), (4) numaralı eşitlik yardımıyla hesaplanabilmektedir. Vanadaki yerel yük kaybı katsayısı (YYKK) kritik noktanın basıncına göre Denklem (7) ile sürekli kendini güncellemektedir.

$Y Y K K[n]=Y Y K k_{0}+K_{P} \times e[n]+K_{I} \times e_{\text {sum }}+K_{D} \times \Delta e[n]$

Başlangıç Yerel Yük Kaybı Katsayısı $(Y Y K k \mathrm{O})$ yaklaşık 12 olarak alınmıştır. Ayrıca $e_{\text {sum }}$ terimi geçmiş hataların toplamı olup, de " $\left[\sum_{i=1}^{n} e[n]\right]$ " olarak şeklinde tanımlanmıştır. Burada kullanılan [ ], içindeki ifadenin üstten sınırlandırılmış olduğunu belirtmektedir ve bu üst sınır integral sarmasının önüne geçilmek için eklenmiştir.

Denklem (7)'de geçen KP, KI ve KD katsayıları modelin stabiliteye ulaşması için yapılan kalibrasyon çalışması sonucunda, kayıp kuvvet derecesinin 1.18 olduğu durum için sırasıyla $-45,-90$ ve -3 olarak, ve kayıp kuvvet derecesinin 1.00 olduğu durum için sırasıyla $-10,-20$ ve -0.5 olarak belirlenmiştir.

Sistemde BDV'nin gerçek zamanlı basınç yönetimini sağladığı senaryolar için 24 ve 28 numaralı düğüm noktalarındaki basınç değerlerinin zaman serileri Şekil 9(a-1)'de verilmiştir. Şekilde görüldüğü üzere gerçek zamanlı basınç yönetimiyle hem 24, hem de 28 numaralı düğüm noktalarındaki basınç değerleri ciddi miktarda azalmıştır. Basınç değerleri her ne kadar sistemin dinamik yapısından dolayı bozucu etkilere maruz kalsa da, yine aynı değere (20 m'ye) yakınsamaya devam etmektedir. Sonuçta basınç yönetiminin yapılmadığı durumda çok yüksek basınç değerlerine (6 senaryoda da 80 m'den yüksek değerlere) sahip olan 28 numaralı düğüm noktasında (Şekil 9(b-d-f-h-j-l)), gerçek zamanlı kontrol vasıtasıyla günün her saatinde 60-65 m civarında basınçların oluşması, bu yöntemle basınç yönetiminde başarı sağlanacağını göstermektedir.

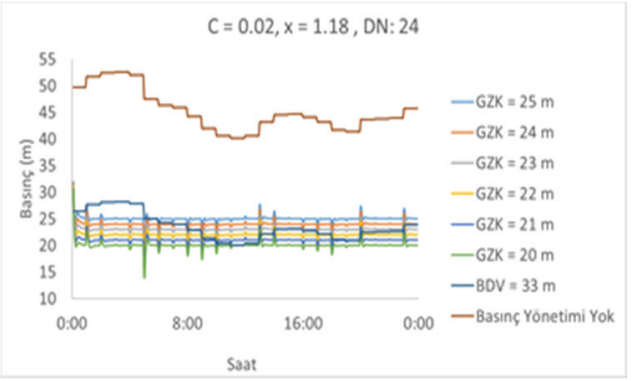

(a)

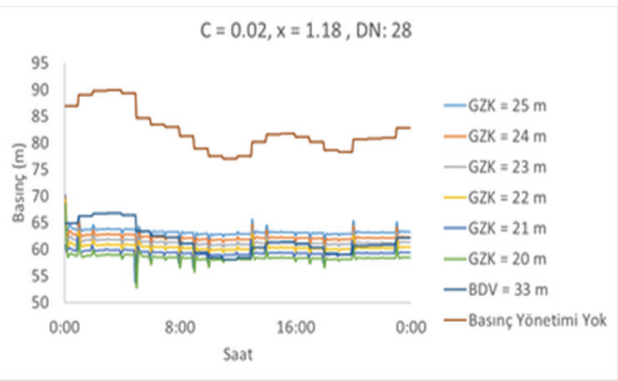

(b) 


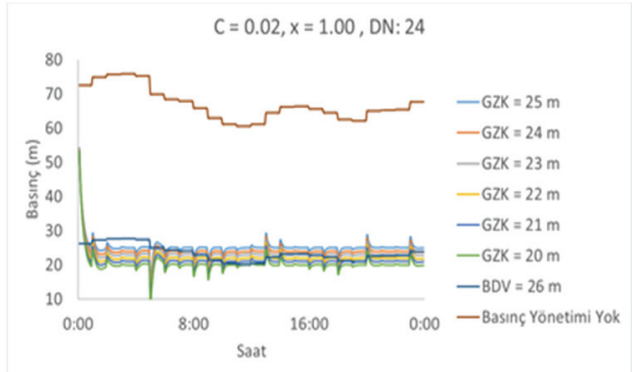

(c)

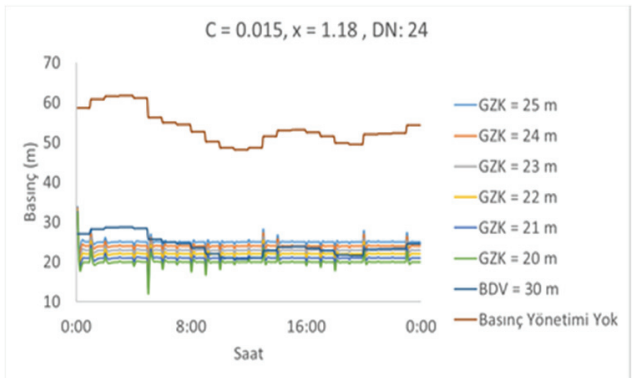

(e)

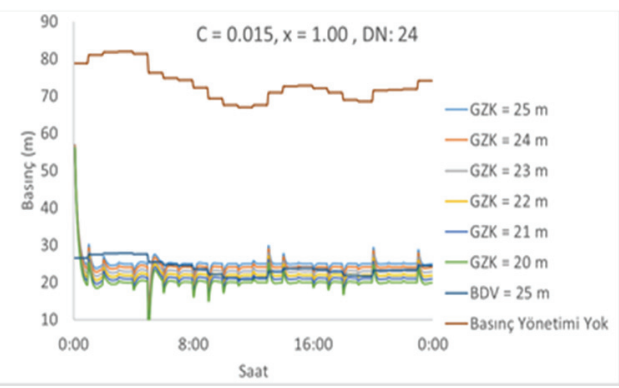

(g)

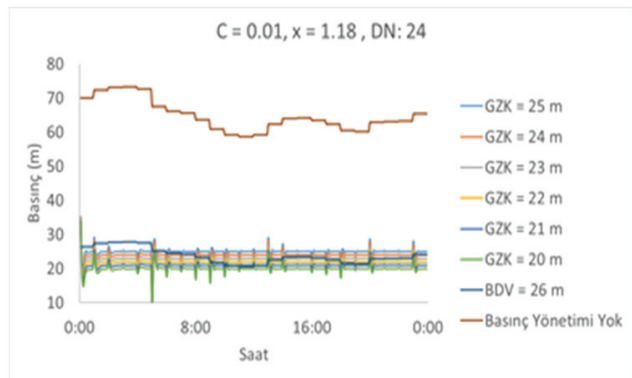

(i)

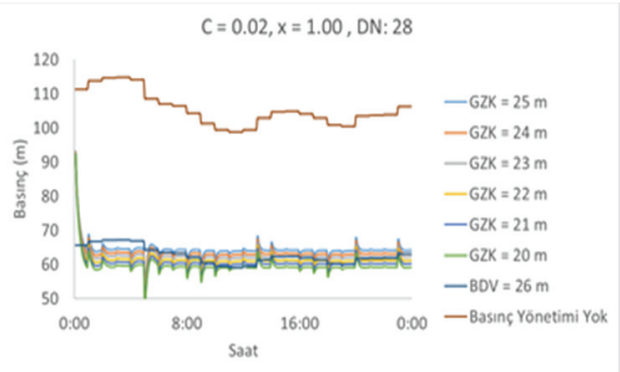

(d)

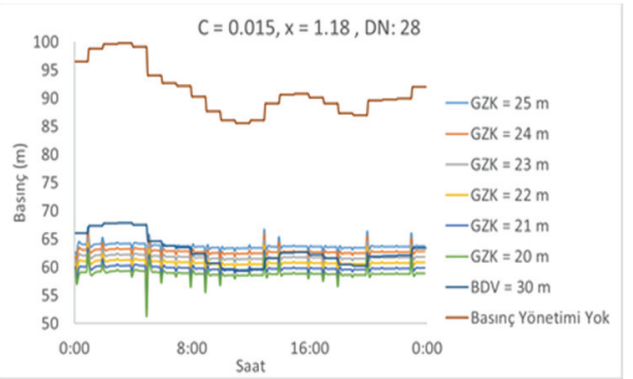

(f)

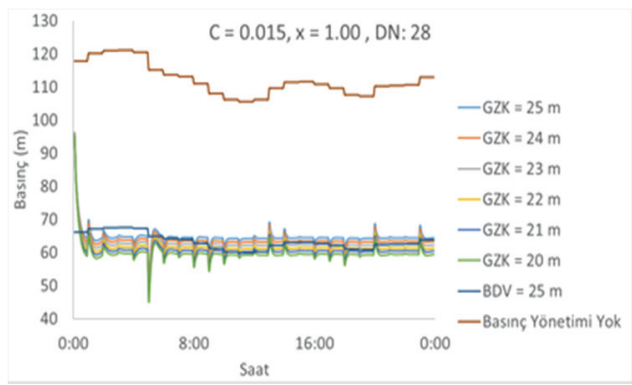

(h)

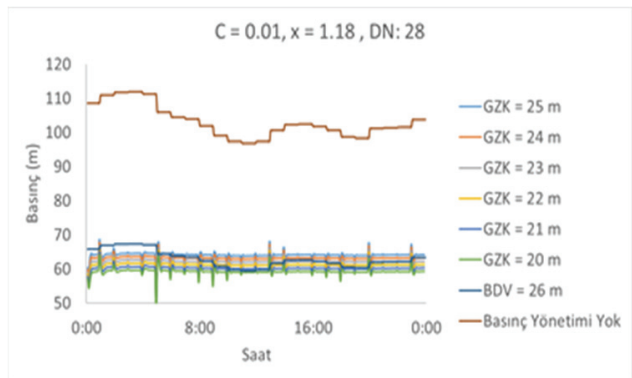

(j) 


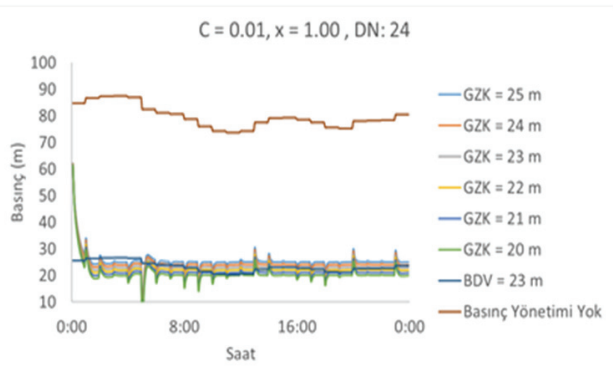

(k)

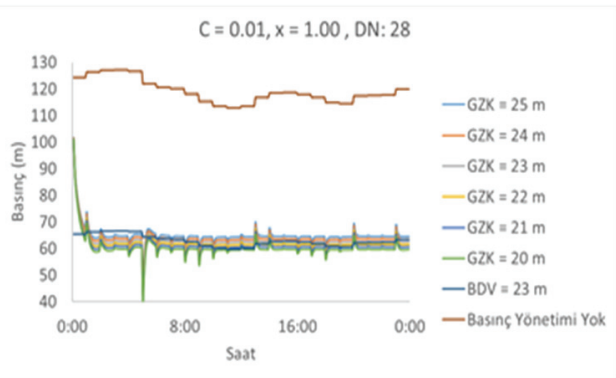

(1)

Şekil 9 - Farklı kayıp katsayıları ve kuvvet dereceleriyle gerçekleştirilen muhtelif basınç yönetimi senaryoları sonucunda 24 ve 28 numaralı düğüm noktalarının 24 saatlik basınç değerleri.

\section{HIPOTETIK MODELDE BASINÇ YÖNETIMININ SU KAYBINA ETKISİ}

Denklem (1)'e göre yapılan su kaybı hesapları neticesinde Çizelge 4'teki sonuçlara ulaşılmıştır. Bu çizelgeye göre, kurulan hipotetik su dağıtım şebekesinde 6 farklı kayıp su senaryosundaki kayıp su oranı değerleri basınç yönetimi yapılmadığında \%53 ile $\% 76$ arasında değişmektedir. Şebeke girişindeki sabit çıkışlı geleneksel basınç düşürücü vana aktif hale getirilip kritik noktada minimum basınç değerinin ihlal edilmeyeceği şekilde çalıştıııldığında ise kayıp su oranı $\% 30$ ile $\% 63$ bandına gerilemiştir.

Çizelge 4 - 6 Farklı Senaryonun 8 Farklı Basınç Yönetimi Durumu için Hesaplanan Su Kaybı Oranlart

\begin{tabular}{|c|c|c|c|c|c|c|c|c|}
\hline \multirow[b]{2}{*}{ Senaryo } & \multicolumn{8}{|c|}{ Kayıp Oranı } \\
\hline & $\begin{array}{l}\text { Basinç } \\
\text { Yönetimi } \\
\text { Yokken }\end{array}$ & BDV & $\begin{array}{c}\mathrm{GZK}=25 \\
\mathrm{~m}\end{array}$ & $\begin{array}{c}\mathbf{G Z K}=24 \\
\mathrm{~m}\end{array}$ & $\begin{array}{c}\mathrm{GZK}=23 \\
\mathrm{~m}\end{array}$ & $\begin{array}{c}\mathrm{GZK}=22 \\
\mathrm{~m}\end{array}$ & $\begin{array}{c}\mathrm{GZK}=21 \\
\mathrm{~m}\end{array}$ & $\begin{array}{c}\mathbf{G Z K}=20 \\
\mathrm{~m}\end{array}$ \\
\hline $1: C=0.02, x=1.18$ & 0.758 & 0.629 & 0.642 & 0.634 & 0.626 & 0.617 & 0.608 & 0.599 \\
\hline $2: C=0.02, x=1.00$ & 0.667 & 0.464 & 0.477 & 0.470 & 0.463 & 0.456 & 0.448 & 0.440 \\
\hline 3: $C=0.015, x=1.18$ & 0.731 & 0.562 & 0.569 & 0.561 & 0.552 & 0.543 & 0.534 & 0.524 \\
\hline 4: $C=0.015, x=1.00$ & 0.617 & 0.395 & 0.405 & 0.398 & 0.391 & 0.384 & 0.377 & 0.369 \\
\hline $5: C=0.01, x=1.18$ & 0.681 & 0.453 & 0.464 & 0.456 & 0.447 & 0.438 & 0.429 & 0.420 \\
\hline $6: C=0.01, x=1.00$ & 0.534 & 0.298 & 0.313 & 0.307 & 0.300 & 0.294 & 0.288 & 0.282 \\
\hline
\end{tabular}

GZK ile basınç yönetimi durumunda sistemdeki su kaybının basınç yönetiminin olmadığ duruma göre daha az olacağı muhakkaktır. Her ne kadar GZK ile basınç yönetimi halinde sabit çıkışlı vanayla yapılan kontrol durumuna göre daha az kayıplar olacağı öngörülse de, kritik noktanın $25 \mathrm{~m}$ ve $24 \mathrm{~m}$ basınçlara sahip olduğu durumlardaki su kaybı miktarı, sabit çıkışıı basınç düşürücü vananın kullanıldığı durumdakine nazaran daha fazla olmaktadır. Buradan bu çalışma kapsamında kurulmuş olan hipotetik su dağıtım şebekesinde, kritik 
noktanın $25 \mathrm{~m}$ ve $24 \mathrm{~m}$ basınç yüksekliğine sahip olması halinde GZK ile basınç yönetimi uygulanmasının istenen faydayı sağlamadığı sonucuna ulaşılmaktadır. Kritik noktanın 23 m basınca sahip olduğu GZK ile basınç yönetimi durumunda ise 1-5 senaryolarında sabit çıkışlı basınç yönetimine göre daha az su kaybı oranı elde edilmiş, sadece 6. Senaryoda az farkla da olsa sabit çıkışlı basınç düşürücü vananın daha avantajlı olduğu görülmüştür. Kritik nokta basıncının 22 m, $21 \mathrm{~m}$ ve $20 \mathrm{~m}$ değerlerini aldığı GZK ile basınç yönetimi durumlarındaysa bu yöntemin faydasının apaçık olduğu görülmüştür.

\section{GERÇEK SU DAĞITIM ŞEBEKESİ MODELINDE GZK UYGULAMASI}

GZK ile basınç yönetimi uygulamasının hipotetik bir şebekede gerçekleştirilmesi her ne kadar kayda değer bir gelişme olsa da, bu basınç yönetimi tarzının gerçek bir su dağıtım şebekesinin hidrolik modelinde fiiliyata dökülmesi elzemdir. Ancak bu sayede GZK ile basınç yönetimi metodunun muteber bir yöntem olup olmadığı anlaşılacaktır. Bu sebeple İstanbul'un Anadolu yakasında bulunan Sultanbeyli ilçesinin bir bölümünde hidrolik modelleme ve basınç yönetimi çalışması icra edilmiştir. Çalışma alanı Şekil 10'da gösterilmiştir. Çalışma alanı, bölgede bulunan Sakarya Depo ve Terfi İstasyonu'ndan beslenen 3 adet DMA'dan (DMA: District Meter Area - İzole Ölçüm Bölgesi) birisi olan DMA-200'dür. Diğer iki DMA'nın ismi Şekil 10'da da görüldüğü üzere DMA-150 ve DMA250'dir. Bu 3 DMA'daki abonelere su iletimini sağlayan Sakarya Depo ve Terfi İstasyonu ise Ömerli Barajı'ndan çıkıp İstanbul Anadolu yakasının güneyindeki Eşref Bitlis Depo ve Terfi İstasyonu'ndan gelen akımla beslenmektedir.

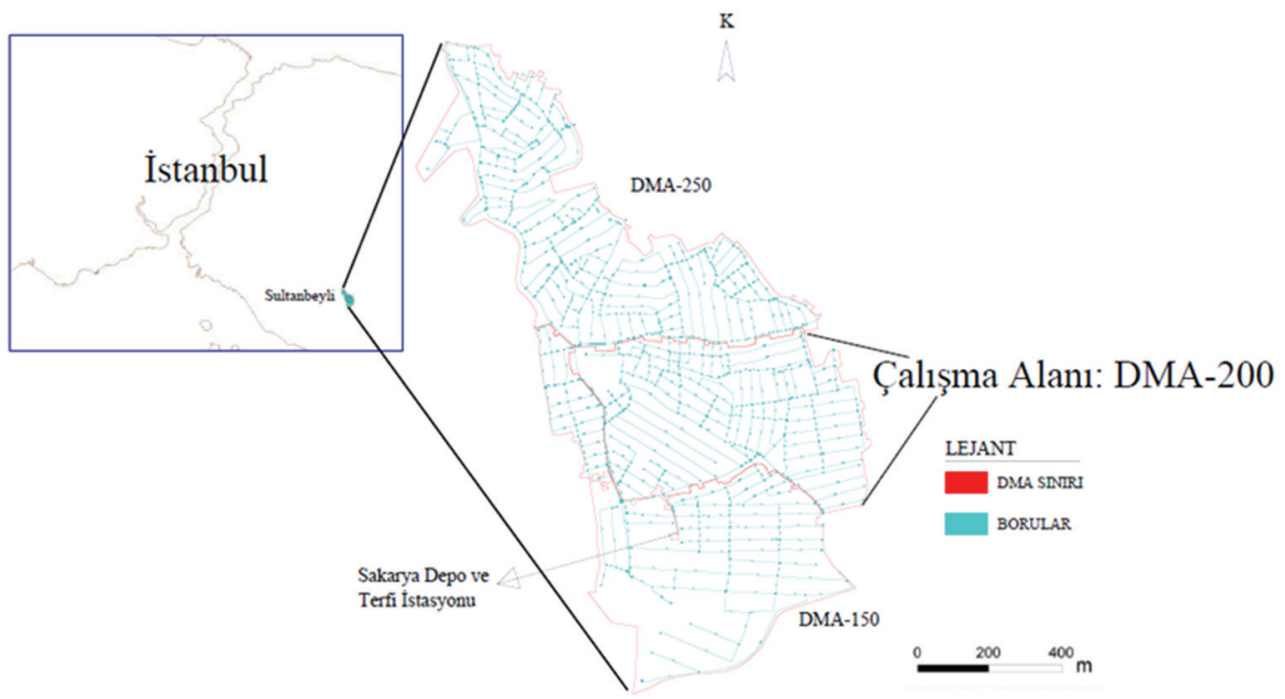

Şekil 10 - Çalışma Alanı

Terfi istasyonu tarafindan beslenen bir bölgede basınç düşürücü vana ile basınç yönetimi yapmak mantıklı gözükmese de bölgenin koşulları bizi buna mecbur kılmaktadır. Zira terfi istasyonunun beslediği DMA'lardan birinde (DMA-150'de) izin verilen minimum servis 
basıncı koşulu az farkla sağlanırken bir diğer DMA'daki (DMA-200'de) ortalama servis basıncı, maksimum izin verilen servis basıncı sınırını aşarak yüksek su kayıplarına sebep olmaktadır. Çalışma alanı olarak seçilen DMA, tam da bahsedilen yüksek basınçların büyük su kayılarına sebep olduğu bölgedir. Bu DMA'da su kaybı oranı \%46 mertebesindedir ki, bu değer abonelere ulaştırılması gereken suyun yaklaşık yarısının sistem dışına çıktığını göstermektedir. Şekil 4'te verilen abone talep paterni esasen bu bölgeye ait olduğu için burada da kullanılmıştır. Buna göre öğlen ve akşam saatlerinde su tüketimi yüksek, gece saatlerinde ise -alışılmış olduğu üzere- tüketim değeri düşüktür.

Çalışma alanı, Şekil 11'de görüldüğü üzere, $182 \mathrm{~m}$ ila $242 \mathrm{~m}$ kotları arasında yer alan düğüm noktalarından oluşmaktadır. Güneydeki $232 \mathrm{~m}$ kotta bulunan Sakarya Depo ve Terfi Merkezi'nden beslenen bölgenin girişinde bir basınç düşürücü vana mevcuttur. Bu basınç düşürücü vana ile yapılan konvansiyonel (sabit çıkışlı) ve inovasyonel (gerçek zamanlı) basınç yönetimi uygulamalarından çalışmanın ilerleyen safhalarında detaylı olarak bahsedilecektir. Fakat bundan önce bölgedeki iki önemli noktanın tanıtılması gerekmektedir. Bu noktalar kritik nokta (J-171) ile maksimum basınçlı noktadır (J-226). Kritik nokta daha önce de bahsedildiği üzere, bölgedeki en yüksek kotlu ve dolayısıyla en düşük basınç değerine sahip noktadır. Maksimum basınçlı nokta ise çalışma alanındaki en düşük kotlu ve isminden de anlaşılacağı üzere en yüksek basınç değerlerine sahip olan noktadır. Her türlü basınç yönetimi uygulamasında yöntemin başarıya ulaşıp ulaşmadığı bu iki noktanın aldığı basınç değerleriyle doğrudan ilgilidir. Bu sebeple bu iki noktadaki basınç değerleri hususi bir önem kazanmaktadır.

Çalışma alanının batısında kotlar yüksek, doğusunda ise düşüktür. Dolayısıyla, kritik noktanın en batıda, maksimum basınçlı noktanın ise en doğuda yer alması tabiidir. Kritik noktanın kotu 242 m, maksimum basınçlı noktanın kotu ise 182 m'dir. Bölgedeki en düşük kotla en yüksek kot arasında $60 \mathrm{~m}$ fark olması, bölgenin basınç yönetiminin verimli bir şekilde gerçekleştirilmesini zorlaştırmaktadır.

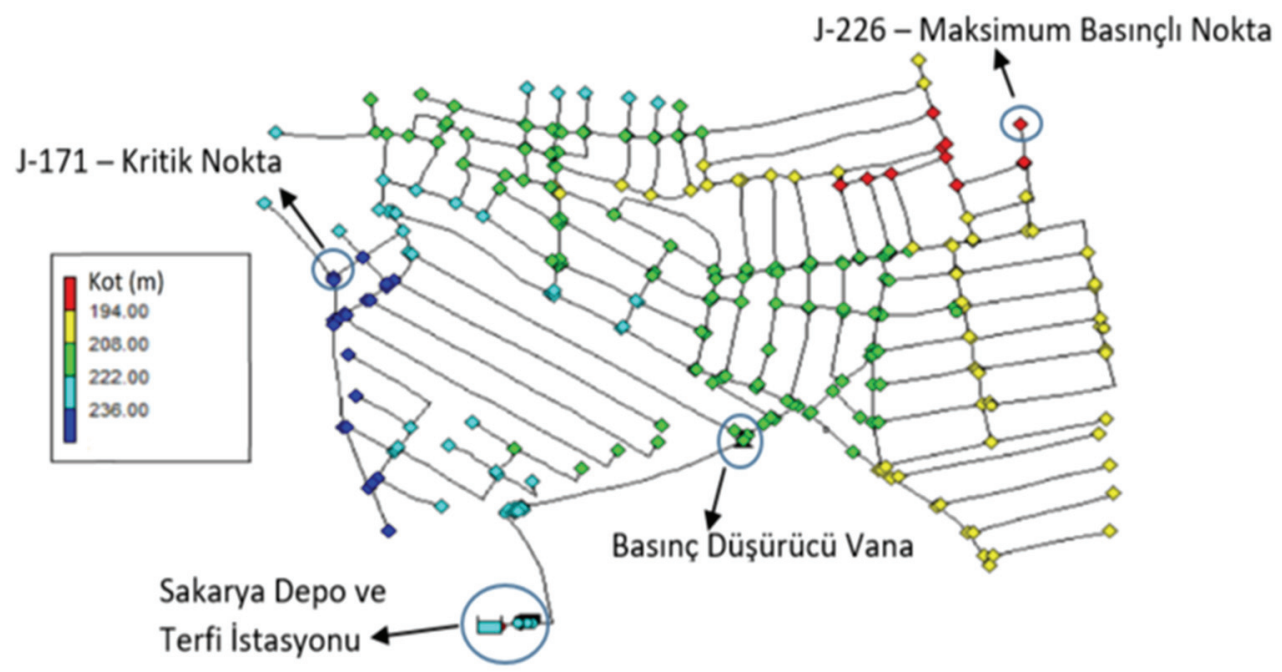

Şekil 11 - Çalışma bölgesi ve bu bölgedeki bazı önemli noktalar 
Bölgedeki su kaybı oranının \% 46 mertebesinde olduğu daha önceden de belirtilmişti. Su kaybı analizi için gerekli olan Kayıp Katsayısı C 0.000153, Kayıp Kuvvet Derecesi x ise 1.18 olarak alınmıştır ki su kaybı oranı \% 46 olsun. Her ne kadar bu çalışmanın önceki safhalarında hipotetik su dağıtım şebekesinde hesap yaparken Kayıp Katsayısı C değeri $10^{-2}$ mertebesinde alınmışken, gerçek su dağıtım şebekesinin modelinde $10^{-5}$ mertebesinde alınması bir çelişki veya tutarsızlık gibi görünse de, su dağıtım şebekesinin içinde bulunduğu koşullara göre bu katsayı $10^{0}$ ile $10^{-10}$ arasında değişebileceği için hipotetik şebekede hassasiyet analizi yapılırken $10^{-2}$ mertebesinde bir Kayıp Katsayısı seçilmesi, gerçek su dağıtım şebekesinde $10^{-5}$ mertebesinde bir Kayıp Katsayısının benimsenmesine engel teşkil etmemektedir [5], [10], [23].

Hidrolik modeli kurulan çalışma alanında basınç yönetimi gerçekleştirilmediğinde Şekil 12'de görüldüğü üzere, kritik noktanın basınc1 $49 \mathrm{~m}$ ile $56 \mathrm{~m}$ arasında değişmekte, maksimum basınçlı noktanın basıncı ise $109 \mathrm{~m}$ ile $116 \mathrm{~m}$ arasında değişmektedir. Su dağıtım şebekelerinde izin verilen maksimum servis basıncının $80 \mathrm{~m}$ olduğu dikkate alınırsa maksimum basınçlı noktanın günün her saatinde bu sınırı ihlal ettiğini görebiliriz. Bu durum, analiz edilen DMA'daki su kaybı miktarının yüksek olmasının sebebini büyük oranda açıklamaktadır. Öyleyse bu şebekede yüksek basınçlar sebebiyle meydana gelen su kayıplarının azaltılmasının yolu öncelikle basınç yönetimi faaliyetinden geçmektedir.

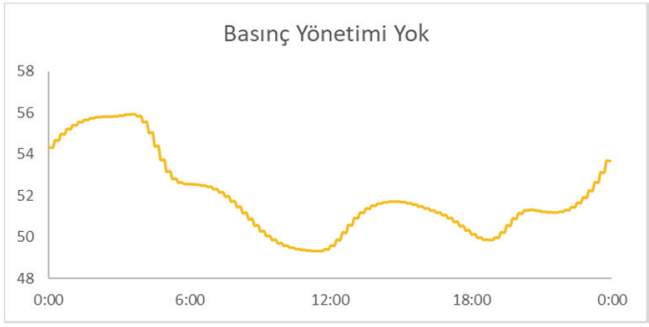

(a)

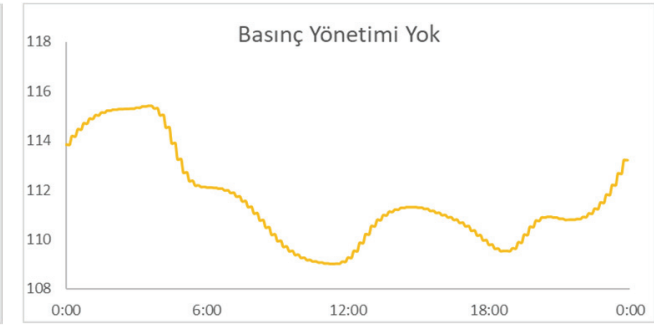

(b)

\section{Şekil 12 - Basınç Yönetimi Yokken Kritik (a) ve Maksimum Basınçlı (b) Noktalarda Basıncın Saatlik Değişimi}

Çalışma alanının girişinde bir basınç düşürücü vananın varlığından daha önce bahsedilmişti. $\mathrm{Bu}$ vana ile öncelikle geleneksel basınç yönetimi uygulaması yapılmıştır. Bu uygulamaya göre şebekenin girişindeki basınç düşürücü vananın menba basıncı ne olursa olsun, bu vana sabit bir çıkış basıncı vermektedir. Bu çalışma kapsamında kurulan hidrolik modelde de su dağıtım şebekesinde izin verilen minimum servis basıncı değerini ihlal etmeyecek en küçük değer 49 m olarak belirlenmiş ve dolayısıyla basınç düşürücü vana, $49 \mathrm{~m}$ sabit çıkış basıncı vermek üzere ayarlanmıştır. Bu şekilde konvansiyonel basınç yönetimi yapılması durumunda ise Şekil 13'te görüldüğü üzere kritik nokta $20.8 \mathrm{~m}$ basınç yüksekliğine kadar düşmüş, maksimum basınçlı nokta ise $80.5 \mathrm{~m}$ değerine inmiştir.

GZK yöntemiyle yapılan basınç yönetiminde ise kritik noktanın basınc1 $20 \mathrm{~m}$ seviyesinde kalacak şekilde şebekenin girişindeki basınç düşürücü vana PID kontrol algoritmasıyla programlanarak sistemdeki basınçlar düşürülmüştür. PID kontrol algoritmasında kullanılan katsayılar olan $\mathrm{K}_{P}, \mathrm{~K}_{\mathrm{I}}$ ve $\mathrm{K}_{\mathrm{D}}$ parametreleri sırasıyla -0.091 , -0.8 ve -0.0001 seçilmiştir. $\mathrm{Bu}$ 
katsayılar basıncın kritik noktada 20 m civarında seyretmesi şartının sağlanması amacıyla özel olarak belirlenmiştir.

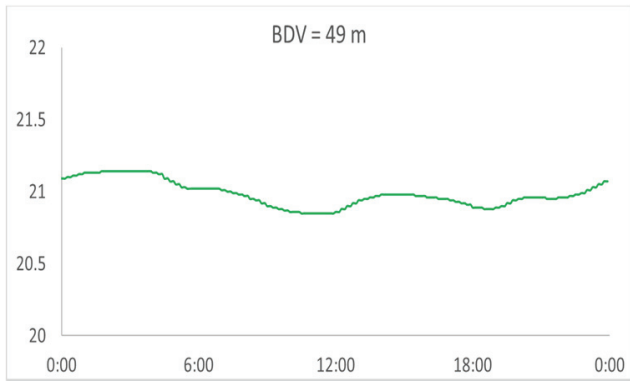

(a)

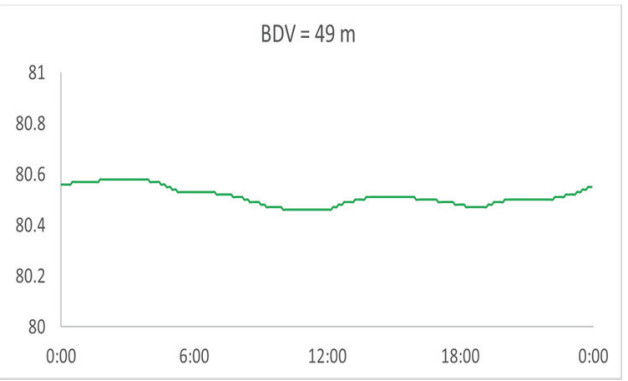

(b)

Şekil 13 - Geleneksel Basınç Yönetiminde Kritik (a) ve Maksimum (b) Basınçlı Noktalarda Basıncın Saatlik Değişimi

Şekil 14'e dikkatli bakıldığında kritik ve maksimum basınçlı noktalardaki basıncın sabit bir değerde kalmadığı ve \pm 5 m'den daha küçük sapmalar gösterdiği anlaşılmaktadır. Her ne kadar kritik noktadaki basıncın 20 m'de sabitlenmesi istense de abone talebinin hızlı değiştiği saatlerde bunu gerçekleştirmek mümkün olamamaktadır. Yine de hedef değerden sapmanın \pm 5 m'den daha az olması basınç yönetiminde istenen faydanın sağlanması için yeterli görülmektedir.

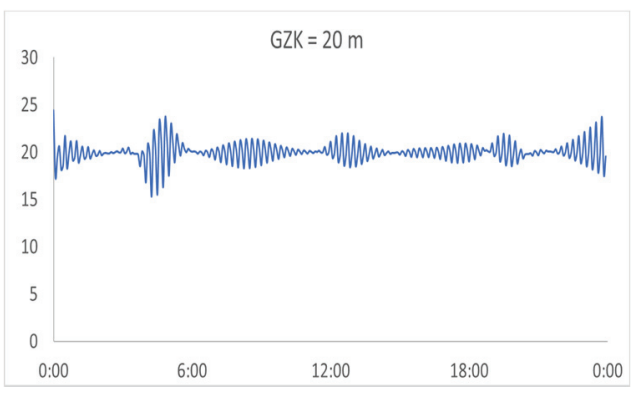

(a)

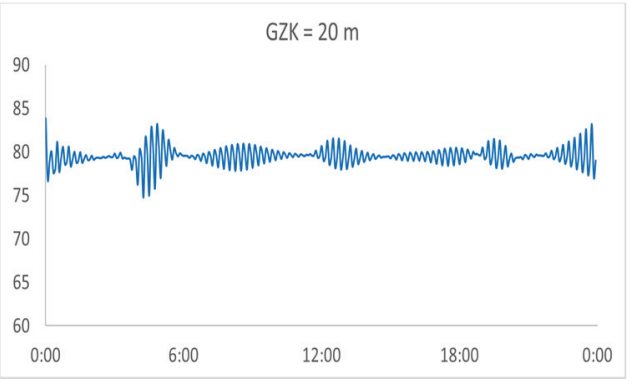

(b)

Şekil 14 - GZK Basınç Yönetiminde Kritik (a) ve Maksimum Basınçlı (b) Noktalarda Basıncın Saatlik Değişimi

Su dağıtım şebekesinin basıncının düşürülmesinin borularda meydana gelebilecek hasar riskini azaltmasının yanında, boru, vana ve bağlantı elemanları gibi unsurların daha uzun ömürlü hizmet verebilmesi için oldukça mühim olduğu bilinmektedir. Fakat basınçların düşürülmesinin en net ve somut faydası muhakkak su kayıplarının azaltılmasıdır. Bu çalışmada da konvansiyonel ve inovasyonel basınç yönetimlerinin su kayıplarına olan etkisi incelendiğinden çalışma bölgesinde yapılan basınç yönetimi faaliyetinin su kayıplarını nasıl etkilediğinden bahsetmek yerinde olacaktır. Şekil 15 'te sisteme giren saatlik debiler, hem 
geleneksel basınç yönetimi için (a), hem de GZK basınç yönetimi için (b) radar grafiğgi olarak gösterilmiştir. Aynı grafiklerde basınç yönetimi yapılmayan durumda sisteme giren debi miktarı da verilmiştir. Bu şekilde ilk dikkati çeken basınç yönetimi yapıldığında sisteme giren su miktarının basınç yönetimi yapılmayan duruma göre daha az olduğudur. Her iki durumda da abonelere verilen su miktarı eşittir fakat basınç yönetimi yapılmadığında oluşan yüksek basınçlar, sistem dışına çıkan su hacmini arttırmaktadır.
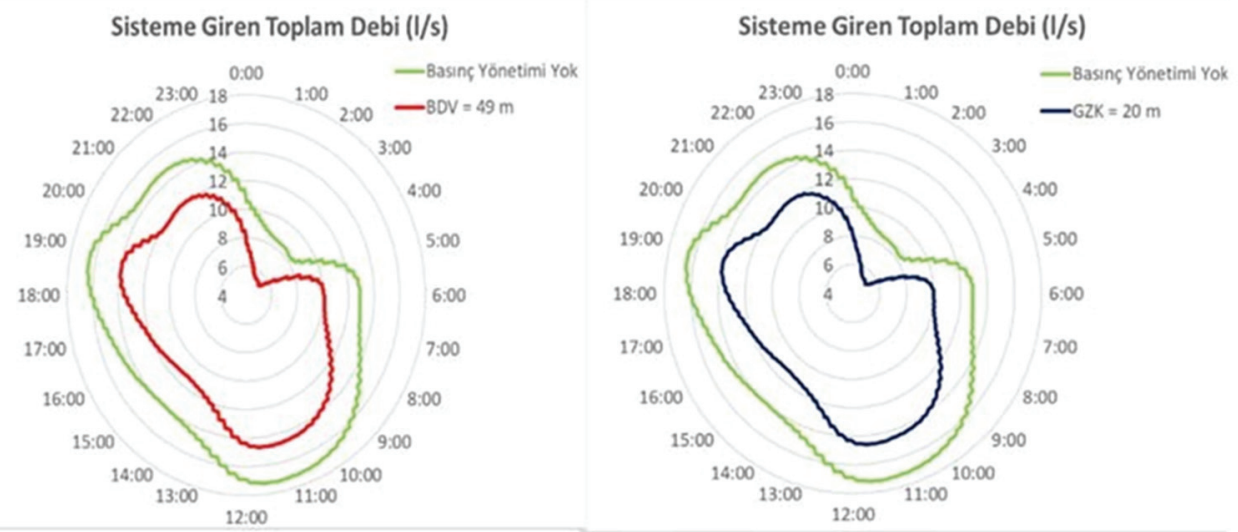

Şekil 15 - Sisteme giren saatlik debi değerleri: a) Geleneksel Basınç Yönetimi, b) GZK ile Basınç Yönetimi

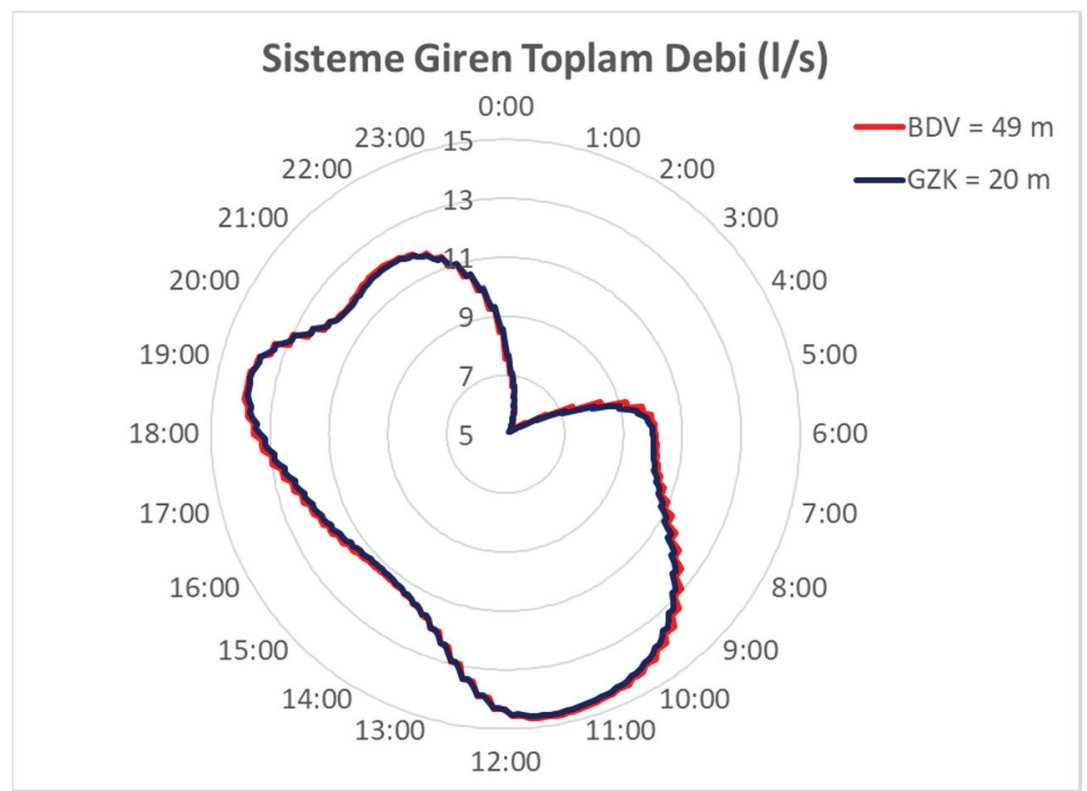

Şekil 16 - Geleneksel Basınç Yönetimi (BDV=49 m) ve GZK ile Basınç Yönetimi (GZK= $20 \mathrm{~m}$ ) sonucunda sisteme giren saatlik debi değerleri 
Çalışma bölgesindeki su kaybı oranının \%46 olduğundan daha önce bahsedilmişti. Basınç yönetimi yapıldığında bu değerin azalacağı açıkça bilinmektedir. Öyle ki, geleneksel sabit çıkışlı BDV ile gerçekleştirilen basınç yönetimi halinde su kaybı oranı \%32.4 olmuştur. GZK ile basınç yönetimi durumunda ise bu değer \%31.85'e düşmüştür. Her iki basınç yönetimi durumunda da su kayıplarının hatırı sayılır miktarda azaltılması, basınç yönetiminin tatbik edilmesinin ne derece zaruri olduğunu göstermesi bakımından dikkat çekicidir. İki basınç yönetimi çeşidinden GZK ile basınç yönetiminin, geleneksel yönteme göre daha fazla miktarda su tasarrufu sağladığı rakamlardan anlaşılmaktadır. İki farklı basınç yönetimi türünün su kayıpları oranları arasındaki fark \%0.55 gibi düşük bir rakam gibi gözükse de bu değer günde $7 \mathrm{~m}^{3}$ 'e denk geldiğinden küçümsenemez bir nicelik arz etmektedir. Şekil 16'da iki farklı basınç yönetiminde sisteme giren debinin saatlik değişimi görülmektedir. Şekilde de görüldüğü üzere GZK ile basınç yönetiminde, geleneksel yönteme göre sisteme giren su miktarı daha azdır. Bu şekil, GZK ile basınç yönetiminin geleneksel basınç yönetimine göre daha başarılı olduğunun bir başka şekilde ifadesidir.

\section{SONUÇ VE DEĞERLENDİRME}

Bu çalışmada iki ana faaliyet gerçekleştirilmiştir: 1. GZK ile basınç yönetimi yapılarak kritik noktanın alacağı farklı basınç değerleriyle su dağıtım şebekesindeki kayıp katsayısı ve kayıp kuvvet derecesinin farklı değerlerinin sistemdeki su kayıplarına etkisi incelenmiştir. 2. Gerçek bir su dağıtım şebekesinin hidrolik modelinde GZK ile basınç yönetimi gerçekleştirilmiş, bu yöntemin su kayıplarını azaltmak bakımından geleneksel yönteme göre daha tercihe şayan olduğu ortaya konmuştur. Sistemdeki basınçları düşürmesi ve kayıp suyu azaltması bakımından GZK ile basınç yönetiminin oldukça faydalı olduğu yapılan analizler sonucunda görülmüştür. Her ne kadar su kaybını azaltıcı bir etkiye sahip olsa da, GZK sisteminin kurulumu ve bakımı için de bir masraf kaleminin açılacağı ortadadır. GZK'nın ekonomik analizinin yapıldığı bir çalışmada [26], tüketim paterninin yüksek salınımlar gösterdiği büyük yerleşim birimlerinde GZK sisteminin uygulanması, kar-zarar analizi yapıldığında makul ve gerekli görülmüştür. Ayrıca şunu da belirtmek gerekir ki, GZK ile basınç yönetiminin yapıldığ 1 DMA'larda sistemin kurulumu ve işletimi dolayısıyla meydana gelecek masrafları asgariye indirmek önemlidir. Bu sebeple vananın sadece kritik noktadan sinyal almasının gerekli olması bir kolaylık olarak öne çıkmaktadır.

Gerçek su dağıtım şebekesinin hidrolik modelinde yürütülen çalışma kapsamında konvansiyonel basınç yönetimiyle tasarruf edilen günlük su miktarı $238.7 \mathrm{~m}^{3}$, GZK ile basınç yönetimiyle kaybı engellenen su hacmi ise günlük $245.8 \mathrm{~m}^{3}$ 'tür. Suyun birim fiyatının Temmuz 2020 itibariyle İstanbul'da 4.5 TL olduğu hesaba katılırsa konvansiyonel basınç yönetimi durumunda sağlanan kazanç yılda yaklaşık 392065 TL, GZK ile basınç yönetimi gerçekleştirildiğinde bir yılda elde edilen kâr ise 403727 TL'dir. Sadece 1 yılda kazanılan miktarın 400000 TL mertebesinde olması basınç yönetiminin neden gerekli olduğunu iyi açıklamaktadır. Bu çalışmada hidrolik model üzerinde tatbikatı yapılan GZK ile basınç yönetimi metodunun geleneksel basınç yönetimi metoduna göre daha fazla kazanç getireceği yukarıdaki rakamlardan anlaşılmaktadır. GZK ile basınç yönetiminden elde edilecek kazanım, geleneksel basınç yönetimiyle sağlanacak kazançtan yılda yaklaşık 12000 TL daha fazladir. 
İçmesuyu dağıtım şebekelerinin temel amacı suyu kaynağından alıp, hedeflenen noktalara istenilen miktarda, kalitede ve basınçta iletebilmektir. Bu hizmeti sunanlar açısından su iletimini en ekonomik şekilde gerçekleştirmek önemlidir. Bu çalışma ekonomik bir faydanın temin edilmesini öngörmektedir. Bununla birlikte GZK ile yönetilen vana, talebe dayalı su tüketimini etkilemeden basıncı ayarladığı için, geleneksel sabit çıkışlı basınç düşürücü vanalara göre abonelere daha kaliteli hizmet sunması açısından da ciddi avantajlara sahiptir.

Su kaybının gerçekleştiği noktaların bulunarak arızaların onarılması elbette çok mühimdir. Fakat ancak efektif bir hidrolik modellemeyle basınç yönetimi faaliyeti sonrasında yapılan boru tamiratları kalıcı sonuç verebilir. Geleneksel sabit çıkışlı basınç düşürücü vanaların şebekenin uygun noktalarına yerleştirildiği basınç yönetimi tarzında sistemdeki kayıp su debisinin azaldığı -bu çalışmada da gösterildiği üzere- bilinmektedir. Ancak GZK ile basınç yönetimiyle su dağıtım şebekelerindeki kayıp su debisinin çok daha fazla azaltılabileceğini, ayrıca eğer sistem bu çalışmada da gösterildiği üzere terfili ise elektrik sarfiyatının da önemli miktarda düşürülebileceğini vurgulamak gerekir. Bu sebeple uygulamada sıklıkla kullanılan geleneksel sabit çıkışılı basınç düşürücü vanaların yanı sıra fayda-zarar analizi yapılarak GZK ile yönetilen basınç düşürücü vanaların kullanımı kesinlikle gözönüne alınmalıdır.

\section{Semboller}

$\mathrm{b}(\mathrm{t}) \quad$ : Bozucu Giriş

BDV : Basınç Düşürücü Vana

C : Kayıp Katsayısı

e[n] : n. Zaman Adımındaki Hata Değeri

n : Zaman Adımı Numarası

e(t) : Hata İşareti

g : Yerçekimi İvmesi

GZK : Gerçek Zamanlı Kontrol

$\mathrm{h}_{\mathrm{k}} \quad$ : Yerel Yük Kaybı

k : Yerel Yük Kaybı Katsayısı

$\mathrm{K}_{\mathrm{P}} \quad$ : Oransallık Sabiti

$\mathrm{K}_{\mathrm{I}} \quad$ : Integral Sabiti

$\mathrm{K}_{\mathrm{D}} \quad$ : Türev Sabiti

$\mathrm{r}(\mathrm{t}) \quad$ : Referans Girişi

P : : Metre Cinsinden Basınç Değeri

PID : Proportional Integral Derivative

$\mathrm{q}_{1} \quad$ : Kayıp Su Debisi

t : : Gerçek Zaman Değeri 


$\begin{array}{ll}\mathrm{u}(\mathrm{t}) & : \text { Sistem Girişi } \\ \mathrm{V} & : \text { Ortalama Akım Hızı } \\ \mathrm{u}^{\prime}(\mathrm{t}) & : \text { Kontrol İşareti } \\ \mathrm{x} & : \text { Kayıp Kuvvet Derecesi } \\ \mathrm{y}(\mathrm{t}) & : \text { Sistem Çıkışı } \\ \Delta \mathrm{e}[\mathrm{n}] & : \text { n. Zaman Adımındaki Hatanın Değişimi } \\ \Delta \mathrm{T} & : \text { Zaman Adımı }\end{array}$

\section{Kaynaklar}

[1] H. Muhammetoğlu and A. Muhammetoğlu, Içme Suyu Temin ve Dă̆gtım Sistemlerindeki Su Kayıplarının Kontrolü El Kitabı. T.C. Orman ve Su İşleri Bakanlığı Su Yönetimi Genel Müdürlüğü, 2017.

[2] I. E. Karadirek, S. Kara, G. Yilmaz, A. Muhammetoglu, and H. Muhammetoglu, "Implementation of Hydraulic Modelling for Water-Loss Reduction Through Pressure Management," Water Resources Management, vol. 26, no. 9, pp. 2555-2568, 2012.

[3] T. M. Walski et al., Advanced Water Distribution Modeling And Management, First Edit. Exton: Bentley Institute Press, 2007.

[4] Ç. Coşkun Dilcan, C. Çapar, A. Korkmaz, Ö. İritaş, Y. Karaaslan, and B. Selek, "İçme Suyu Şebekelerinde Görülen Su Kayılarının Dünyada ve Ülkemizdeki Durumu," Anahtar Dergisi, vol. 354, pp. 10-18, 2018.

[5] L. S. Araujo, H. Ramos, and S. T. Coelho, "Pressure Control for Leakage Minimisation in Water Distribution Systems Management," pp. 133-149, 2006.

[6] A. Campisano, E. Creaco, and C. Modica, "RTC of Valves for Leakage Reduction in Water Supply Networks," Journal of Water Resources Planning and Management, vol. 136, no. February, pp. 138-141, 2010.

[7] A. Campisano, C. Modica, and L. Vetrano, "Calibration of Proportional Controllers for the RTC of Pressures to Reduce Leakage in Water Distribution Networks," water Resources Planning and Management, vol. 138, no. August, pp. 377-384, 2012.

[8] E. Creaco, A. Campisano, M. Franchini, and C. Modica, "Unsteady Flow Modeling of Pressure Real-Time Control in Water Distribution Networks," Journal of Water Resources Planning and Management, vol. 143, no. 9, p. 04017056, 2017.

[9] A. Campisano, C. Modica, S. Reitano, R. Ugarelli, and S. Bagherian, "Field-Oriented Methodology for Real-Time Pressure Control to Reduce Leakage in Water Distribution Networks," Journal of Water Resources Planning and Management, vol. 142, no. 12, p. $04016057,2016$. 
[10] L. Berardi, D. Laucelli, R. Ugarelli, and O. Giustolisi, "Hydraulic system modelling : background leakage model calibration in Oppegård municipality," Procedia Engineering, vol. 119, pp. 633-642, 2015.

[11] L. Berardi, D. Laucelli, R. Ugarelli, and O. Giustolisi, "Leakage management: planning remote real time controlled pressure reduction in Oppegård municipality," Procedia Engineering, vol. 119, pp. 72-81, 2015.

[12] N. Fontana, M. Giugni, L. Glielmo, G. Marini, and F. Verrilli, "Real-time control of a PRV in water distribution networks for pressure regulation: Theoretical framework and laboratory experiments," Journal of Water Resources Planning and Management, vol. 144, no. 1, pp. 1-14, 2018.

[13] N. Fontana, M. Giugni, L. Glielmo, G. Marini, and F. Verrilli, "Real-Time Control of a PRV in Water Distribution Networks for Pressure Regulation: Theoretical Framework and Laboratory Experiments," vol. 144, no. 2010, pp. 1-14, 2018.

[14] N. Fontana, M. Giugni, L. Glielmo, G. Marini, and R. Zollo, "Real-Time Control of Pressure for Leakage Reduction in Water Distribution Network: Field Experiments," Journal of Water Resources Planning and Management, vol. 144, no. 3, p. 04017096, 2018.

[15] J. E. Van Zyl and R. Malde, "Evaluating the pressure-leakage behaviour of leaks in water pipes," Journal of Water Supply: Research and Technology - AQUA, vol. 66, no. 5, pp. 287-299, 2017.

[16] E. Creaco, A. Campisano, and C. Modica, "Testing behavior and effects of PRVs and RTC valves during hydrant activation scenarios," Urban Water Journal, vol. 15, no. 3, pp. 218-226, 2018.

[17] M. Gökbulut, Otomatik Kontrol Sistemleri. Seçkin Yayıncılık, 2019.

[18] Ç. Gül, "PID Kontrol Algoritması ve Karakteristikleri: Elektroniğe Dair Herşey,” 2019.

[19] E. Todini and S. Pilati, "A gradient method for the analysis of pipe networks," Proc.of Computer Applications for Water Supply and Distribution, no. May, 1987.

[20] L. A. Rossman, “Epanet 2 Users Manual.” Drinking Water Research Division, Risk Reduction Engineering Laboratory, Office of Research and Development, U.S. Environmental Protection Agency, Cincinnati, 2000.

[21] S. Kıran, "Mevcut İçme Suyu Dağıtım Şebekesinin Hidrolik Model Yardımıyla Yönetimi," Istanbul Teknik Üniversitesi, 2018.

[22] O. Giustolisi, D. Savic, and Z. Kapelan, "Pressure-Driven Demand and Leakage Simulation for Water Distribution Networks," Journal of Hydraulic Engineering, vol. 134, no. 5, pp. 626-635, 2008.

[23] M. Nicolini, C. Giacomello, and K. Deb, "Calibration and Optimal Leakage Management for a Real Water Distribution Network," Journal of Water Resources Planning and Management, vol. 137, no. 1, pp. 134-142, 2011. 
[24] J. Schwaller and J. E. van Zyl, "Modeling the pressure-leakage response of water distribution systems based on individual leak behavior," Journal of Hydraulic Engineering, vol. 141, no. 5, pp. 1-8, 2015.

[25] S. Hamilton and R. Mckenzie, Water Management and Water Loss, vol. 13. London, 2014.

[26] E. Creaco and T. Walski, "Operation and Cost-Effectiveness of Local and Remote RTC," Journal of Water Resources Planning and Management, vol. 144, no. 11, pp. 1$10,2018$. 